Gynecologic and

Obstetric Investigation
Gynecol Obstet Invest 2016;81:15-22

DOI: $10.1159 / 000381620$
Received: July 9, 2014

Accepted after revision: March 11, 2015

Published online: June 17, 2015

\title{
Polymorphisms in Genes Coding for Cytokines, Mannose-Binding Lectin, Collagen Metabolism and Thrombophilia in Women with Cervical Insufficiency
}

\author{
Iben Sundtoft ${ }^{a}$ Niels Uldbjerg ${ }^{a}$ Rudi Steffensen ${ }^{b}$ Steffen Sommer ${ }^{d}$ \\ Ole Bjarne Christiansen ${ }^{c, e}$ \\ ${ }^{a}$ Department of Obstetrics and Gynecology, Aarhus University Hospital, Aarhus, Departments of ${ }^{b}$ Clinical \\ Immunology and ' $\mathrm{Cb}$ (metrics and Gynecology, Aalborg University Hospital, Aalborg, ${ }^{\mathrm{d}}$ Department of Obstetrics and

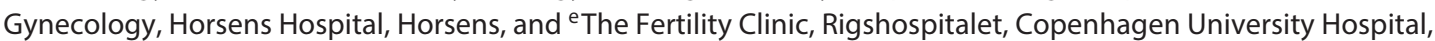 \\ Copenhagen, Denmark
}

\section{Key Words}

Cervical insufficiency · Preterm birth · Cytokines · Mannosebinding lectin $\cdot$ Single nucleotide polymorphisms tide polymorphisms in the IL6 gene and the MBL2 gene and low MBL levels related to the latter polymorphism may increase the risk of preterm birth due to cervical insufficiency.

(c) 2015 S. Karger AG, Basel

\section{Introduction}

Deliveries, whether term or preterm, are believed to share a common pathway of uterine contractility, cervical dilation and activation of the membranes. Term labor is a result of physiological activation of the components of the common pathway, whereas a pathological activation of the pathway may lead to preterm birth (PTB). The pathological processes implicated have been categorized as intrauterine infection/inflammation, uterine ischemia, uterine overdistension, abnormal allograft reaction, allergy, cervical insufficiency and hormonal disorders [1].

Cervical insufficiency is characterized by painless cervical dilation in the second trimester of pregnancy in the absence of uterine contractions causing second-trimester miscarriage or extreme PTB. The lack of pathognomonic findings and clear diagnostic criteria makes it difficult to

\section{KARGER}

E-Mail karger@karger.com

www.karger.com/goi
(C) 2015 S. Karger AG, Basel

0378-7346/15/0811-0015\$39.50/0
Iben Sundtoft, MD, $\mathrm{PhD}$

Department of Obstetrics and Gynecology

Aarhus University Hospital

Palle Juul-Jensens Boulevard 99, DK-8200 Aarhus N (Denmark)

E-Mail sundtoft@ dadlnet.dk 
ascertain the actual incidence of cervical insufficiency, but estimates vary around $0.5-1 \%[2,3]$.

Cervical insufficiency may be caused by a constitutional deficiency of the components of the cervical connective tissue. Thus the cervical collagen concentration has been shown to be lower in women with a history of cervical insufficiency $[4,5]$. Congenital uterine malformation and surgery on the cervix including conization are other proposed causes of cervical insufficiency [6-9]. Cerclage treatment has been shown to be of benefit in selected cases of cervical insufficiency [10-12].

There is also some evidence that proinflammatory cytokines, such as interleukin $1 \alpha$ (IL-1 $\alpha$ ), IL- $1 \beta$, IL- 6 and tumor necrosis factor $\alpha$ (TNF- $\alpha$ ), play a role in cervical insufficiency as their levels in amniotic fluid are higher in women undergoing emergency cerclage surgery compared with normal pregnant women [13]. There may also be an increased risk of late miscarriage or PTB $[14,15]$ in women with thrombophilia caused by thrombosis in the placental vessels, but in theory this is expected to cause intrauterine fetal death rather than PTB due to cervical insufficiency.

The involvement of genetic factors in the pathophysiology of PTB and cervical insufficiency has been hypothesized based on studies of familiar aggregation of PTB $[16,17]$ and case-control studies of presumed susceptibility genes [18-26].

A single study on genes related to cervical connective tissue reported an association between polymorphisms in genes for collagen $1 \alpha 1$ (COL1A1), transforming growth factor-beta (TGF- $\beta$ ) and cervical insufficiency [20]. Single nucleotide polymorphisms (SNPs) in genes associated with immune response and inflammation may be associated with recurrent miscarriage and second-trimester miscarriage. An association between polymorphisms in genes coding for proinflammatory cytokines and PTB has been demonstrated in several studies [19, 21-26]; the evidence for the IL6 -174 genotype [27] and genetic polymorphisms predisposing to low plasma levels of mannose-binding lectin (MBL) $[18,19]$ being associated to PTB must a priori be considered strong. However, studies of the association between these SNPs and cervical insufficiency have not been published. In the present study we therefore aimed to study whether relevant DNA variants in the maternal genome were associated with second-trimester miscarriage and PTB due to cervical insufficiency. Sixteen genetic markers previously reported as possibly associated with second-trimester miscarriage and PTB were studied, thirteen SNPs from seven relevant cytokine and collagen genes in addition to functional, relevant polymorphisms in the mannose-binding lectin 2 (MBL2) gene, and two thrombophilia-related SNPs. Finally serum MBL levels were measured in patients and controls.

\section{Subjects and Methods}

\section{Study Population}

At the Departments of Obstetrics and Gynecology, Aarhus University Hospital Skejby, Aarhus, Horsens Hospital, Horsens, and Rigshospitalet, Copenhagen University Hospital, Copenhagen, 100 Danish women were enrolled in this case-control study from September 2007 to August 2010. Cases and controls were recruited simultaneously. General exclusion criteria for both cases and controls were age $<18$ years, non-Caucasian ethnicity, a history of cervical dysplasia or conization, connective tissue disorder, menopause, pregnancy in the preceding 12 months, placental abruption, multiple pregnancy or fetal abnormality in the index pregnancies. Cases and controls were not further matched.

\section{Cases}

To identify women with cervical insufficiency, medical charts were studied for all patients with discharge ICD-10 codes for cervical insufficiency (DO343), late miscarriage (DO03, gestational age $>15$ weeks), threatening PTB (DO472) as well as external and abdominal cerclage (KMAB00, KLDD10). Approximately 850 women had a relevant discharge code, 262 of whom had clinical evidence of dilation of the cervix without labor in the second trimester. Women with vaginal bleeding or intrauterine infections during pregnancy or other symptoms uncharacteristic of cervical insufficiency, previous term birth, incomplete history or any of the aforementioned exclusion criteria were excluded after review of the medical charts. After critical review of the medical charts the inclusion criteria was met by 62 women, of whom 31 accepted to participate; 14 women did not respond, 5 were pregnant and $12 \mathrm{did}$ not want to participate for other reasons. One woman was subsequently excluded because of failed blood sampling.

\section{Controls}

The control group consisted of 70 normal women hospitalized for sterilization or surgical procedures as part of the diagnosis and treatment of sterility, endometriosis, dysmenorrhea, premenopausal menometrorrhagia, leiomyoma, ovarian cysts or other benign conditions not involving the cervix. Exclusion criteria were any of the general criteria as well as previous PTB (birth before 37 weeks of gestation) or second-trimester miscarriage.

\section{Blood Collection and Analysis}

Blood samples were obtained from both cases and controls for analysis of activated partial thromboplastin time as a screening for presence of the lupus anticoagulant, IgG and IgM anticardiolipin antibodies (EliA anticardiolipin IgG and IgM, Phadia ApS, Alleroed, Denmark) and $\beta 1$-glycoprotein- 1 antibodies (EliA anti- $\beta 2$ glycoprotein IgG and IgM, Phadia ApS). Serum MBL was determined by a monoclonal antibody-based time-resolved immunofluorometric assay described in a previous study [28].

Genotyping was carried out in six SNPs in the MBL2 gene, three located in the promoter region: $M B L 2-619 \mathrm{G}>\mathrm{C}$ (called $\mathrm{H} / \mathrm{L}$, respectively; rs11003125), MBL2 -290 G > C (called Y/X;
16

Gynecol Obstet Invest 2016;81:15-22 DOI: $10.1159 / 000381620$
Sundtoft/Uldbjerg/Steffensen/Sommer/ Christiansen 
rs7096206), MBL2 -66 C > T (called P/Q; rs7095891) and three located in the first exon of the structural $M B L 2$ gene: $M B L 2+154$ C > T (called A/D; rs5030737), MBL2 +161 G > A (called A/B; rs1800450), and $M B L 2+170 \mathrm{G}>\mathrm{A}$ (called A/C; rs1800451). Relevant SNPs in the COL1A1 gene coding for collagen 1 a 1 (rs1800012) [20], in the factor II gene (rs1799963) and the factor $V$ Leiden gene (rs6025) were also investigated. Finally, 12 SNPs located in seven cytokine or cytokine-related genes were investigated: $I L 1 A+4845$ $\mathrm{G}>\mathrm{T}(\mathrm{rs} 17561), I L 1 A+889 \mathrm{C}>\mathrm{T}(\mathrm{rs} 1800587), I L 1 B+31 \mathrm{~T}>\mathrm{C}$ (rs1143627), IL1B-511C > T (rs16944),IL6-174G > C (rs1800795), IL6R G > A (rs8192282), IL10 -1082 A > G (rs1800896), LTA -82 $\mathrm{G}>\mathrm{C}$ (rs746868), LTA +252 A > G (rs909253), TNFA -308 G > A (rs1800629), TNFA -857 C > T (rs1799724), and TGFB +174 G > $\mathrm{C}$ (rs1800471). Information about SNP IDs and nucleotide changes is given in online supplementary table 1 (for all online suppl. material, see www.karger.com/doi/10.1159/000381620). The SNPs were selected based on the available literature and hypothesized proinflammatory pathways and are mainly those that have been previously reported to be associated with recurrent or late miscarriages or PTB.

\section{Genotyping Technique}

DNA was extracted from EDTA-stabilized blood samples using a Maxwell 16 blood DNA purification kit (Promega, Madison, Wis., USA). All SNPs were tested using a real-time polymerase chain reaction (PCR) technique using minor groove binder TaqMan probes (Applied Biosystems, Foster City, Calif., USA). Information about primers, probes and array references is presented in online supplementary table 1 . For 10 SNPs in cytokine genes predesigned SNP Genotyping Assays (Applied Biosystems) were used, for four SNPs (LTA -82 G > C, TGB1 $74 \mathrm{G}>\mathrm{C}$, factor II G20210 G > A, and factor $V$ Leiden $1691 \mathrm{G}>\mathrm{A}$ ) primers and probes were designed for this study, and finally the remaining six SNPs (in the MBL2 gene) were investigated as previously described $[29,30]$. DNA amplification was carried out in $5 \mu \mathrm{l}$ containing $20 \mathrm{ng}$ DNA, $0.9 \mu \mathrm{M}$ primers and $0.2 \mu \mathrm{M}$ probes (final concentrations). The product was amplified using TaqMan Universal PCR Master Mix (Applied Biosystems). Reactions were performed in 384-well plates with the following protocol on a GeneAmp PCR 9700 or a 7900 HT Sequence Detection System: $95^{\circ} \mathrm{C}$ for $10 \mathrm{~min}$, followed by $40 \mathrm{cycles}$ at $95^{\circ} \mathrm{C}$ for $15 \mathrm{~s}$ and $60^{\circ} \mathrm{C}$ for $1 \mathrm{~min}$. To determine genotypes, end-point fluorescence was read on the 7900 HT Sequence Detection Systems using SDS version 2.3 software.

\section{Statistical Analysis}

Differences in demographic characteristics between the cervical insufficiency and the control group were compared using the Wilcoxon rank-sum test. Frequencies of SNPs were determined and recorded as allele frequencies (proportion of positive chromosomes) and genotypes (proportion of women possessing homozygous or heterozygous combinations of SNPs). With regard to the SNPs in the MBL2 gene, recognized haplotypes and genotypes encompassing SNPs in the promoter region and exon 1 were established. The Hardy-Weinberg equilibrium was estimated separately for each polymorphism in the case and the control group, respectively. Comparisons of frequencies of individual SNPs and MBL genotypes associated with high, intermediate or low MBL concentrations [31] in patients with cervical insufficiency and controls were assessed by the $\chi^{2}$ test. A two-sided $p$ value $<0.05$ was

Cytokine Genes, Mannose-Binding Lectin and Cervical Insufficiency considered statistically significant. Odds ratios (ORs) were reported with 95\% confidence interval (95\% CI). Statistical analysis was performed with Stata (statistical software package version 10.1 for Windows, StataCorp LP).

\section{Results}

The baseline characteristics of the included participants are shown in table 1. Detailed clinical data on the women with cervical insufficiency are shown in online supplementary table 2 . We found no difference in the characteristics of the women with cervical insufficiency who did not participate $(n=31)$ in the study compared to those participating $(n=31)$ (results not shown).

All SNPs were in Hardy-Weinberg equilibrium in both the patient and the control group, except for the SNPs in $I L 1 B-31$ (both patient and control group) and IL $1 B-511$ (control group).

Two genotypes were significantly associated with cervical insufficiency compared with controls: homozygous carriers of the IL6 -174 G allele (genotype GG) (OR 3.1, $95 \%$ CI 1.3-7.4, $\mathrm{p}=0.01$; table 2) and carriers of $M B L 2$ genotypes associated with low and intermediate MBL levels (OR 3.3, 95\% CI 1.2-9.0, p = 0.01; table 3).

We found no significant difference between the distributions of other genotypes in the two groups (table 2). There was a non-significant $(\mathrm{p}=0.20)$ difference in the frequency of carriers of the $\mathrm{T}$ polymorphism in the in COL1A1 gene (table 4).

Serum MBL levels were significantly lower in women with cervical insufficiency (median $408 \mathrm{ng} / \mathrm{ml}$, 95\% CI $118-1,463)$ than in controls $(1,985 \mathrm{ng} / \mathrm{ml}, 95 \%$ CI $1,265-$ 2,735 , p < 0.01; table 3). $40 \%$ of women with cervical insufficiency had MBL levels <200 $\mathrm{ng} / \mathrm{ml}$ compared with $18.8 \%$ of controls (OR 2.9, 95\% CI 1.1-7.4).

There were no significant differences in the prevalence of increased activated partial thromboplastin time or positivity for IgM and IgG anticardiolipin and IgM and IgG $\beta 2$-glycoprotein-1 antibodies between the patients and controls. The rate of biomarkers related to the antiphospholipid syndrome in patients was $<3.3 \%$. None of the patients or controls carried the factor II 20210 G > A SNP, whereas $7.1 \%$ of patients and $10.1 \%$ of controls carried the factor $V 1691 \mathrm{G} / \mathrm{A}$ SNP ( $=0.64)$.

A significant difference in parity was found between cases and controls, with more multiparous and no nulliparous subjects in the group of women with cervical insufficiency. The higher frequency of multiparity in the case group was due to a higher rate of stillbirths and ex- 
Table 1. Baseline characteristics of patients with cervical insufficiency $(n=30)$ and controls $(n=70)$

\begin{tabular}{|c|c|c|c|c|c|}
\hline & \multicolumn{2}{|c|}{ Cervical insufficiency } & \multicolumn{2}{|c|}{ Controls } & \multirow[t]{2}{*}{$\mathrm{p}$ value } \\
\hline & n (\%) & median (range) & n (\%) & median (range) & \\
\hline Age, years & & $35(22-45)$ & & $31(18-49)$ & $<0.01$ \\
\hline Birth & & $2(0-4)$ & & $1(0-6)$ & $<0.01$ \\
\hline Nullipara & $3(10)$ & & $30(43)$ & & $<0.01$ \\
\hline Primipara & $4(13)$ & & $16(23)$ & & 0.28 \\
\hline Multipara & $23(77)$ & & $24(34)$ & & $<0.01$ \\
\hline Neonatal death $^{\mathrm{a}}$ & $20(67)$ & $1(0-3)$ & 0 & & $<0.01$ \\
\hline Ectopic pregnancy & $2(7)$ & $0(0-1)$ & 0 & & 0.03 \\
\hline Early miscarriage & $12(40)$ & $0(0-3)$ & $13(19)$ & $0(0-2)$ & 0.02 \\
\hline Late miscarriage & $14(47)$ & $0(0-3)$ & 0 & & $<0.01$ \\
\hline Induced abortion & $10(33)$ & $0(0-4)$ & $11(16)$ & $0(0-2)$ & 0.03 \\
\hline Cerclage treatment & & & 0 & & \\
\hline Transcervical & $17(57)$ & $1(0-3)$ & 0 & & $<0.01$ \\
\hline Transabdominal & $16(53)$ & $1(0-1)$ & 0 & & $<0.01$ \\
\hline Uterine malformations ${ }^{\mathrm{b}}$ & $4(13)$ & $0(0-1)$ & 0 & & $<0.01$ \\
\hline
\end{tabular}

Birth: gestational age $\geq 22$ weeks; early miscarriage: gestational age $<15$ weeks; late miscarriage: gestational age 15-22 weeks; induced abortion: gestational age $<12$ weeks.

${ }^{a}$ Defined as death within the first 28 days of life. ${ }^{b}$ Defined as uterine septum, uni- or bicornuate uterus.

treme PTBs (online suppl. table 2). Excluding all nulliparous controls $(\mathrm{n}=30)$ did not change the results; homozygous carriers of the IL6 -174 GG genotype had an OR of 3.5 (95\% CI 1.2-10.7, $\mathrm{p}=0.01)$ and carriers of $M B L 2$ genotypes associated with low and intermediate MBL levels had an OR of 2.6 (95\% CI 0.9-7.7, p = 0.05) for cervical insufficiency when compared with controls.

\section{Discussion}

This is the first study of a possible association between several maternal DNA variants associated with predisposition to inflammation, immune dysregulation or collagen metabolism and cervical insufficiency. We found that the IL6 -174 GG genotype and polymorphisms in the $M B L 2$ gene associated with low or intermediate levels of plasma MBL were significantly associated with cervical insufficiency. In addition, by measuring the MBL protein directly in serum, the median levels were significantly lower and the frequency of low $(<200 \mathrm{ng} / \mathrm{ml})$ MBL levels was significantly higher in women with cervical insufficiency than controls.

The mechanism linking immunoregulatory genetic polymorphisms to late adverse pregnancy outcomes has been proposed as a predisposition to an abnormal inflam- matory response following an otherwise harmless microbial colonization of the cervix or amniotic membranes or microbial invasion of the amniotic cavity. Increased levels of inflammatory cytokines have been found in the amniotic fluid of women in preterm labor ending in PTB. Proinflammatory cytokines, such as TNF- $\alpha$, IL- $1 \beta$ and IL- 6 , are believed to induce synthesis and release of prostaglandins and metalloproteinases, stimulating uterine contractions, softening of the cervix and weakening of the chorioamniotic membranes [32], whereas anti-inflammatory cytokines such as IL-10 and TGF- $\beta 1$ modulate the effect of the proinflammatory cytokines. These findings make it reasonable to study associations between cervical insufficiency and polymorphisms in genes coding for pro- and anti-inflammatory cytokines.

It has been reported that carriers of the IL6 -174 CC genotype have significantly lower plasma concentrations of IL- 6 than individuals with the GG and GC genotypes [33], and it is reasonable to suggest that the latter genotypes are also associated with higher amniotic fluid concentrations of IL-6 and therefore predisposition to PTB. Our study of a highly selected population consisting of women with classic cervical insufficiency, excluding those with signs of intrauterine infections, labor or vaginal bleeding at time of delivery, confirms the association between the maternal IL6-174 GG genotype and
18

Gynecol Obstet Invest 2016;81:15-22 DOI: $10.1159 / 000381620$
Sundtoft/Uldbjerg/Steffensen/Sommer/ Christiansen 
Table 2. Allele and genotype frequencies of SNPs in cytokine or cytokine receptor genes in patients with cervical insufficiency $(n=30)$ and controls $(n=70)$

\begin{tabular}{|c|c|c|c|c|c|c|c|c|}
\hline \multirow[t]{2}{*}{ Gene polymorphisms } & & \multicolumn{2}{|c|}{ Cervical insufficiency } & \multicolumn{2}{|c|}{ Controls } & \multirow[t]{2}{*}{ OR } & \multirow[t]{2}{*}{$95 \% \mathrm{CI}$} & \multirow[t]{2}{*}{$\mathrm{p}$ value } \\
\hline & & $\mathrm{n}$ & $\%$ & $\mathrm{n}$ & $\%$ & & & \\
\hline \multirow[t]{5}{*}{ IL1A $889(\mathrm{C}>\mathrm{T})$} & $\mathrm{CC}$ & 13 & 43.3 & 32 & 45.7 & 0.9 & $0.3-2.3$ & 0.83 \\
\hline & $\mathrm{CT}$ & 15 & 50.0 & 31 & 44.3 & 1.3 & $0.5-3.2$ & 0.60 \\
\hline & TT & 2 & 6.7 & 7 & 10.0 & 0.6 & $0.1-3.7$ & 0.59 \\
\hline & allele C & 41 & 68.3 & 95 & 67.9 & 1.0 & - & 0.95 \\
\hline & allele $\mathrm{T}$ & 19 & 31.7 & 45 & 32.1 & & & \\
\hline \multirow[t]{5}{*}{ IL1A $4845(\mathrm{G}>\mathrm{T})$} & GG & 13 & 43.3 & 32 & 45.7 & 0.9 & $0.3-2.3$ & 0.83 \\
\hline & GT & 16 & 53.3 & 31 & 44.3 & 1.4 & $0.6-3.7$ & 0.41 \\
\hline & $\mathrm{TT}$ & 1 & 3.3 & 7 & 10.0 & 0.3 & $0.0-2.6$ & 0.26 \\
\hline & allele G & 42 & 70.0 & 95 & 67.9 & 1.1 & $0.5-2.3$ & 0.77 \\
\hline & allele $\mathrm{T}$ & 18 & 30.0 & 45 & 32.1 & & & \\
\hline \multirow[t]{6}{*}{$I L 1 B-31(\mathrm{~T}>\mathrm{C})$} & TT & 11 & 36.7 & 33 & 47.1 & 0.6 & $0.2-1.7$ & 0.33 \\
\hline & $\mathrm{TC}$ & 13 & 43.3 & 23 & 32.9 & 1.6 & $0.6-4.1$ & 0.32 \\
\hline & CC & 6 & 20.0 & 14 & 20.0 & 1.0 & - & 1.0 \\
\hline & $\mathrm{CC}+\mathrm{CT}$ & 19 & 63.3 & 37 & 52.9 & 1.5 & $0.6-4.1$ & 0.30 \\
\hline & allele T & 25 & 41.7 & 51 & 36.4 & 0.8 & $0.4-1.6$ & 0.48 \\
\hline & allele C & 35 & 58.3 & 89 & 63.6 & & & \\
\hline \multirow[t]{6}{*}{$I L 1 B-511(\mathrm{C}>\mathrm{T})$} & $\mathrm{CC}$ & 11 & 36.7 & 33 & 47.1 & 0.6 & $0.2-1.7$ & 0.33 \\
\hline & CT & 13 & 43.3 & 24 & 34.3 & 1.5 & $0.6-3.8$ & 0.39 \\
\hline & $\mathrm{TT}$ & 6 & 20.0 & 13 & 18.6 & 1.1 & $0.3-3.6$ & 0.87 \\
\hline & $\mathrm{TT}+\mathrm{CT}$ & 19 & 63.3 & 37 & 52.9 & 1.5 & $0.6-4.1$ & 0.30 \\
\hline & allele C & 35 & 58.3 & 90 & 64.3 & 0.8 & $0.4-1.5$ & 0.43 \\
\hline & allele $\mathrm{T}$ & 25 & 41.7 & 50 & 35.7 & & & \\
\hline \multirow[t]{6}{*}{ IL6 -174 (G > C) } & GG & 16 & 53.3 & 19 & 27.1 & 3.1 & $1.3-7.4$ & 0.01 \\
\hline & GC & 11 & 36.7 & 33 & 47.1 & 0.7 & $0.3-1.6$ & 0.33 \\
\hline & $\mathrm{CC}$ & 3 & 10.0 & 18 & 25.7 & 0.3 & $0.1-1.2$ & 0.08 \\
\hline & $\mathrm{GG}+\mathrm{GC}$ & 27 & 90.0 & 52 & 74.3 & 3.1 & $0.8-11.5$ & 0.08 \\
\hline & allele G & 43 & 71.7 & 71 & 50.7 & 2.4 & $1.3-4.7$ & 0.01 \\
\hline & allele C & 17 & 28.3 & 69 & 49.3 & & & \\
\hline \multirow[t]{5}{*}{$\operatorname{IL6R}(\mathrm{G}>\mathrm{A})$} & GG & 21 & 70.0 & 42 & 60.0 & 1.6 & $0.6-4.4$ & 0.34 \\
\hline & GA & 9 & 30.0 & 26 & 37.1 & 0.7 & $0.3-2.0$ & 0.49 \\
\hline & $\mathrm{AA}$ & 0 & 0.0 & 2 & 2.9 & & & \\
\hline & allele $\mathrm{G}$ & 51 & 85.0 & 110 & 78.6 & 1.5 & $0.7-4.0$ & 0.29 \\
\hline & allele A & 9 & 15.0 & 30 & 21.4 & 1.5 & $0.7-4.0$ & 0.29 \\
\hline \multirow[t]{5}{*}{ IL10-1082 (A > C) } & AA & 11 & 36.7 & 16 & 22.9 & 1.9 & $0.7-5.4$ & 0.15 \\
\hline & $\mathrm{AC}$ & 12 & 40.0 & 34 & 48.6 & 0.7 & $0.3-1.8$ & 0.43 \\
\hline & $\mathrm{CC}$ & 7 & 23.3 & 20 & 28.6 & 0.8 & $0.2-2.2$ & 0.59 \\
\hline & allele A & 34 & 56.7 & 66 & 47.1 & 1.5 & $0.8-2.8$ & 0.22 \\
\hline & allele C & 26 & 43.3 & 74 & 52.9 & & & \\
\hline \multirow[t]{5}{*}{$L T A-82(\mathrm{C}>\mathrm{G})$} & $\mathrm{CC}$ & 9 & 30.0 & 28 & 40.0 & 0.6 & $0.2-1.7$ & 0.34 \\
\hline & CG & 15 & 50.0 & 34 & 48.6 & 1.1 & $0.4-2.7$ & 0.90 \\
\hline & GG & 6 & 20.0 & 8 & 11.4 & 1.9 & $0.5-7.1$ & 0.26 \\
\hline & allele G & 33 & 55.0 & 90 & 65.3 & 0.7 & $0.4-1.3$ & 0.22 \\
\hline & allele C & 27 & 45.0 & 50 & 35.7 & & & \\
\hline \multirow[t]{5}{*}{ LTA $252(\mathrm{~A}>\mathrm{G})$} & $\mathrm{AA}$ & 14 & 46.7 & 27 & 38.6 & 1.4 & $0.5-3.6$ & 0.45 \\
\hline & $\mathrm{AG}$ & 12 & 40.0 & 31 & 44.3 & 0.8 & $0.3-2.2$ & 0.69 \\
\hline & GG & 4 & 13.3 & 12 & 17.1 & 0.7 & $0.2-2.8$ & 0.63 \\
\hline & allele A & 40 & 66.7 & 85 & 60.7 & 1.3 & $0.7-2.6$ & 0.43 \\
\hline & allele G & 20 & 33.3 & 55 & 39.3 & & & \\
\hline
\end{tabular}


Table 2 (continued)

\begin{tabular}{|c|c|c|c|c|c|c|c|c|}
\hline \multirow[t]{2}{*}{ Gene polymorphisms } & & \multicolumn{2}{|c|}{ Cervical insufficiency } & \multicolumn{2}{|c|}{ Controls } & \multirow[t]{2}{*}{ OR } & \multirow[t]{2}{*}{$95 \%$ CI } & \multirow[t]{2}{*}{$\mathrm{p}$ value } \\
\hline & & $\mathrm{n}$ & $\%$ & $\mathrm{n}$ & $\%$ & & & \\
\hline \multirow[t]{5}{*}{ TGFB1 $74(\mathrm{G}>\mathrm{C})$} & GG & 27 & 90.0 & 55 & 78.6 & 2.5 & $0.6-14.2$ & 0.17 \\
\hline & GC & 3 & 10.0 & 14 & 20.0 & 0.4 & $0.1-1.8$ & 0.22 \\
\hline & $\mathrm{CC}$ & 0 & 0.0 & 1 & 1.4 & - & - & 0.51 \\
\hline & allele $\mathrm{G}$ & 57 & 95.0 & 124 & 88.6 & 2.5 & $0.7-13.6$ & 0.16 \\
\hline & allele C & 3 & 5.0 & 16 & 11.4 & & & \\
\hline \multirow[t]{5}{*}{ TNFA $-308(\mathrm{G}>\mathrm{A})$} & GG & 22 & 79.3 & 47 & 67.1 & 1.3 & $0.5-4.0$ & 0.54 \\
\hline & GA & 6 & 20.0 & 22 & 31.4 & 0.5 & $0.2-1.6$ & 0.24 \\
\hline & $\mathrm{AA}$ & 2 & 6.7 & 1 & 1.4 & 4.9 & $0.2-294.8$ & 0.16 \\
\hline & allele $\mathrm{G}$ & 50 & 83.3 & 116 & 82.9 & 1.0 & - & 0.93 \\
\hline & allele A & 10 & 16.7 & 24 & 17.1 & & & \\
\hline \multirow[t]{5}{*}{ TNFA $857(\mathrm{C}>\mathrm{T})$} & $\mathrm{CC}$ & 25 & 83.3 & 63 & 90.0 & 0.6 & $0.1-2.5$ & 0.35 \\
\hline & $\mathrm{CT}$ & 5 & 16.7 & 6 & 8.6 & 2.1 & $0.5-9.2$ & 0.24 \\
\hline & $\mathrm{TT}$ & 0 & 0.0 & 1 & 1.4 & & & 0.51 \\
\hline & allele C & 55 & 91.7 & 132 & 94.3 & 1.5 & $0.4-5.5$ & 0.49 \\
\hline & allele T & 5 & 8.3 & 8 & 5.7 & & & \\
\hline
\end{tabular}

Table 3. MBL2 genotypes associated with high, intermediate and low MBL levels and plasma MBL levels measured by ELISA in women with cervical insufficiency $(\mathrm{n}=30)$ and controls $(\mathrm{n}=70)$

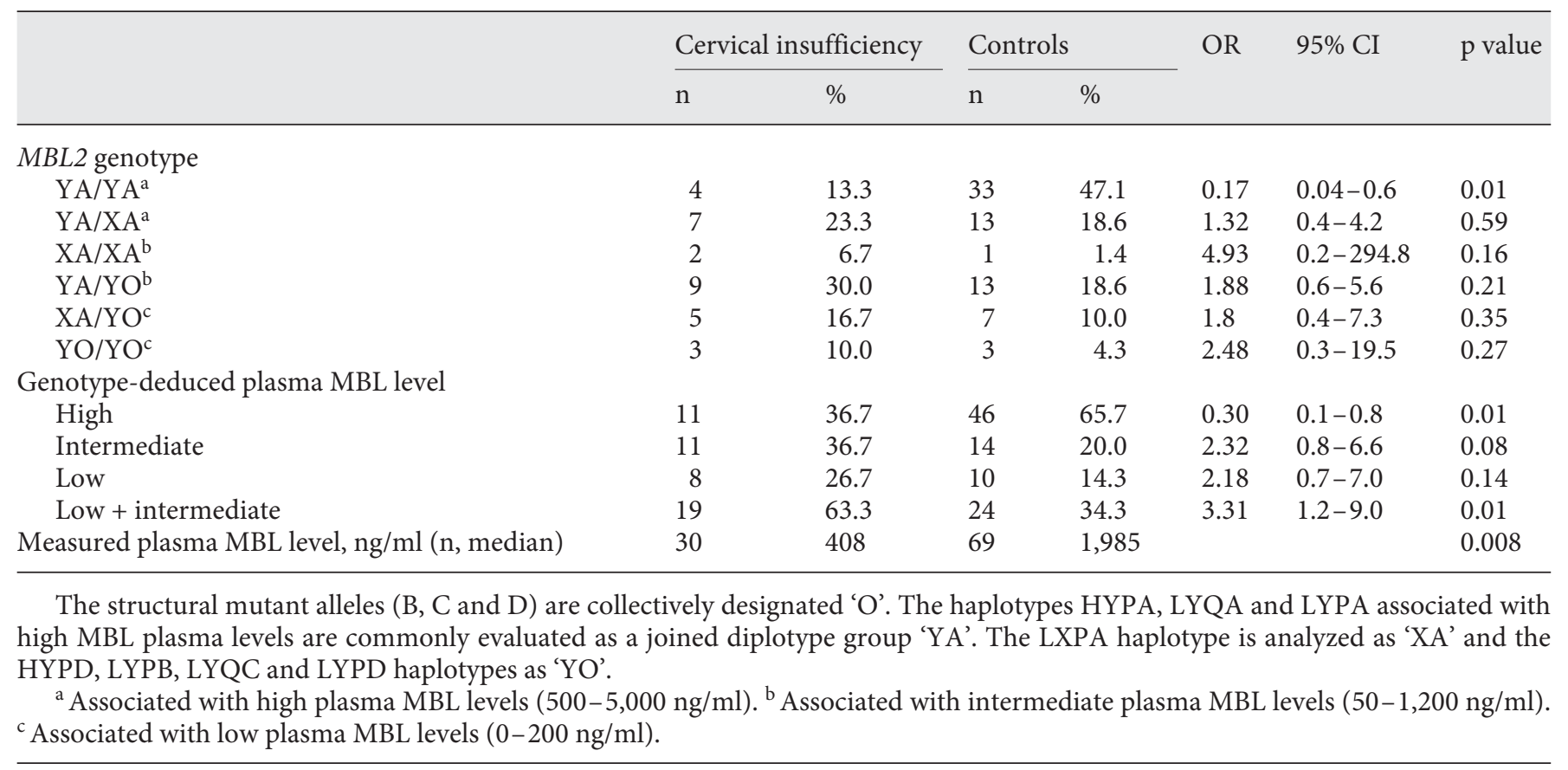

cervical insufficiency. In accordance, $\mathrm{Wu}$ et al. [27] in a meta-analysis found the SNP IL6 - 174 genotype CC to be protective against PTB in women of European descent.
Inability to prevent microbial invasion of the amniotic cavity can also, in theory, be caused by a genetic immunodeficiency such as a deficiency of MBL. Our study found significant associations between low serum levels 
Table 4. Association between the COL1A1 1023 polymorphisms related to connective tissue metabolism and cervical insufficiency (cervical insufficiency: $\mathrm{n}=30$; controls: $\mathrm{n}=70$ )

\begin{tabular}{|c|c|c|c|c|c|c|c|}
\hline \multirow[t]{2}{*}{ COL1A1 $1023 \mathrm{G}>\mathrm{T}$} & \multicolumn{2}{|c|}{ Cervical insufficiency } & \multicolumn{2}{|c|}{ Controls } & \multirow[t]{2}{*}{ OR } & \multirow[t]{2}{*}{$95 \% \mathrm{CI}$} & \multirow[t]{2}{*}{$\mathrm{p}$ value } \\
\hline & $\mathrm{n}$ & $\%$ & $\mathrm{n}$ & $\%$ & & & \\
\hline GG & 17 & 56.7 & 49 & 70.0 & 0.6 & $0.2-1.5$ & 0.20 \\
\hline GT & 12 & 40.0 & 20 & 28.6 & 1.7 & $0.6-4.4$ & 0.26 \\
\hline TT & 1 & 3.3 & 1 & 1.4 & 2.4 & $0.3-189.4$ & 0.53 \\
\hline $\mathrm{TT}+\mathrm{GT}$ & 13 & 43.3 & 21 & 30.0 & 1.8 & $0.7-4.7$ & 0.20 \\
\hline Allele T & 46 & 76.7 & 118 & 84.3 & 0.6 & $0.3-1.4$ & 0.20 \\
\hline Allele G & 14 & 23.3 & 22 & 15.7 & 1.6 & $0.7-3.7$ & 0.20 \\
\hline
\end{tabular}

$\mathrm{n}=$ Number of participants.

of the MBL protein, genotypes associated with low or intermediate MBL levels and cervical insufficiency. MBL binds to carbohydrates on the surfaces of microorganisms, which results in complement activation and thereby elimination of the microorganisms, but MBL can probably also modulate secretion of cytokines such as TNF- $\alpha$ from the lymphocytes. The mechanism through which low MBL may contribute to PTB (and cervical insufficiency) is unknown, and studies on the association between MBL deficiency and PTB are conflicting [18, 3438].

We found a trend for an association between cervical insufficiency and a SNP in the COL1A1 gene that may predispose to an increased connective tissue metabolism, which support findings by Warren et al. [20].

There are several limitations to this study. The small sample size can cause a type 2 error, as the study population will be underpowered to detect weak genetic effects that may be of importance in a complex condition as cervical insufficiency. We tested 12 SNPs in cytokine-related genes, and regarding some of these we had no prior hypothesis about which may be associated with cervical insufficiency; therefore, it could be argued that some of the $\mathrm{p}$ values in table 2 should be corrected by the Bonferroni method. However, based on the meta-analysis by $\mathrm{Wu}$ et al. [27], the IL6 -174 GG genotype was a priori expected to confer susceptibility to cervical insufficiency, and therefore in our view the $\mathrm{p}$ value for this genotype needs no correction. Similarly, the MBL2 genotypes associated with low and intermediate MBL levels and the COL1A1 $\mathrm{TT}+\mathrm{GT}$ genotypes have previously been reported to be associated with late miscarriage and cervical insufficiency and were therefore a priory candidate susceptibility genetic variants not needing Bonferroni correction.

Cytokine Genes, Mannose-Binding Lectin and Cervical Insufficiency
The strength of this study is the highly selected group of cases meeting the criteria of classic cervical insufficien$c y$ : a painless progressive dilation and effacement of the uterine cervix during the second trimester of pregnancy without vaginal bleeding or signs of intrauterine infection. It adds to the strength that cases and controls all originated from the same ethnic population (Caucasians), although our findings may not allow generalization to other ethnic populations.

In conclusion, our results confirm that both polymorphisms in the $M B L 2$ gene associated with low or intermediate levels of serum MBL and low plasma MBL levels increase the risk of PTB due to cervical insufficiency. Furthermore, the IL6 -174 GG genotype also seems to confer susceptibility to PTB due to cervical insufficiency, which confirms findings in more heterogeneous populations. Overall our results support the theory of cervical insufficiency being, in part, a genetic disorder.

\section{Acknowledgments}

This study was supported by grants from the Danish Agency for Science, Technology and Innovation, Aarhus University Research Foundation, Toyota Foundation, Sophus Jacobsen Foundation, Augustinus Foundation, Hede Nielsen Foundation, Organon Gynecological Research Grant, Aase and Ejnar Danielsen Foundation, Johannes M. Klein Foundation and King Christian 10th Foundation.

\section{Statement of Ethics}

This study was approved by the local Ethics Committee (project identification number M-20070185) and the Danish Data Protection Agency (project identification number 2007-41-0834). Informed consent was obtained from all participants. 


\section{References}

1 Romero R, Espinoza J, Kusanovic JP, Gotsch F, Hassan S, Erez O, Chaiworapongsa T, Mazor M: The preterm parturition syndrome. BJOG 2006;113:17-42.

$\checkmark 2$ Harger JH: Cerclage and cervical insufficiency: an evidence-based analysis. Obstet Gynecol 2002;100:1313-1327.

-3 Lidegaard O: Cervical incompetence and cerclage in Denmark 1980-1990. A register based epidemiological survey. Acta Obstet Gynecol Scand 1994;73:35-38.

-4 Oxlund BS, Ortoft G, Bruel A, Danielsen CC, Oxlund $\mathrm{H}$, Uldbjerg N: Cervical collagen and biomechanical strength in non-pregnant women with a history of cervical insufficiency. Reprod Biol Endocrinol 2010;8:92.

5 Petersen LK, Uldbjerg N: Cervical collagen in non-pregnant women with previous cervical incompetence. Eur J Obstet Gynecol Reprod Biol 1996;67:41-45.

6 Rackow BW, Arici A: Reproductive performance of women with mullerian anomalies. Curr Opin Obstet Gynecol 2007;19:229-237.

-7 Arbyn M, Kyrgiou M, Simoens C, Raifu AO, Koliopoulos G, Martin-Hirsch P, Prendiville W, Paraskevaidis E: Perinatal mortality and other severe adverse pregnancy outcomes associated with treatment of cervical intraepithelial neoplasia: meta-analysis. BMJ 2008;337:a1284.

8 Ortoft G, Henriksen T, Hansen E, Petersen L: After conisation of the cervix, the perinatal mortality as a result of preterm delivery increases in subsequent pregnancy. BJOG 2010; 117:258-267.

-9 Liu Y, Qui HF, Tang Y, Chen J, Lv J: Pregnancy outcome after the treatment of loop electrosurgical excision procedure or cold-knife conization for cervical intraepithelial neoplasia. Gynecol Obstet Invest 2014;77:240-244.

10 Owen J, Hankins G, Iams JD, Berghella V, Sheffield JS, Perez-Delboy A, Egerman RS, Wing DA, Tomlinson M, Silver R, Ramin SM, Guzman ER, Gordon M, How HY, Knudtson EJ, Szychowski JM, Cliver S, Hauth JC: Multicenter randomized trial of cerclage for preterm birth prevention in high-risk women with shortened midtrimester cervical length. Am J Obstet Gynecol 2009;201:375.e1-375.e8.

- 11 Burger NB, Brolmann HA, Einarsson JI, Langebrekke A, Huirne JA: Effectiveness of abdominal cerclage placed with laparotomy or laparoscopy: systematic review. J Minim Invasive Gynecol 2011;18:696-704.

$\checkmark 12$ El-Nashar SA, Paraiso MF, Rodewald K, Muir T, Abdelhafez F, Lazebnik N, Bedaiwy MA: Laparoscopic cervicoisthmic cerclage: technique and systematic review of the literature. Gynecol Obstet Invest 2013;75:1-8.

13 ParkJC, Kim DJ, Kwak-Kim J: Upregulated amniotic fluid cytokines and chemokines in emergency cerclage with protruding membranes. Am J Reprod Immunol 2011;66:310-319.

14 Velez DR, Fortunato SJ, Thorsen P, Lombardi SJ, Williams SM, Menon R: Preterm birth in Caucasians is associated with coagulation and inflammation pathway gene variants. PLoS 25 Simhan HN, Krohn MA, Roberts JM, Zeevi A, One 2008;3:e3283.

15 Robertson L, Wu O, Langhorne P, Twaddle S, Clark P, Lowe GDO, Walker ID, Greaves M, Brenkel I, Regan L, Greer IA: Thrombophilia in pregnancy: a systematic review. Br J Haematol 2006;132:171-196

16 Wilcox AJ, Skjaerven R, Lie RT: Familial patterns of preterm delivery: maternal and fetal contributions. Am J Epidemiol 2008;167: 474-479.

17 Svensson AC, Sandin S, Cnattingius S, Reilly M, Pawitan Y, Hultman CM, Lichtenstein P: Maternal effects for preterm birth: a genetic epidemiologic study of 630,000 families. Am J Epidemiol 2009;170:1365-1372.

18 Bodamer OA, Mitterer G, Maurer W, Pollak A, Mueller MW, Schmidt WM: Evidence for an association between mannose-binding lectin 2 (MBL2) gene polymorphisms and preterm birth. Genet Med 2006;8:518-524.

19 Annells MF, Hart PH, Mullighan CG, Heatley SL, Robinson JS, Bardy P, McDonald HM: Interleukins- $1,-4,-6,-10$, tumor necrosis factor, transforming growth factor-beta, FAS, and mannose-binding protein $\mathrm{C}$ gene polymorphisms in Australian women: risk of preterm birth. Am J Obstet Gynecol 2004;191:20562067.

20 Warren JE, Silver RM, Dalton J, Nelson LT, Branch DW, Porter TF: Collagen 1Alpha1 and transforming growth factor-beta polymorphisms in women with cervical insufficiency. Obstet Gynecol 2007;110:619-624.

21 Hollegaard MV, Grove J, Thorsen P, Wang X, Mandrup S, Christiansen M, Norgaard-Pedersen B, Wojdemann K, Tabor A, Attermann J, Hougaard DM: Polymorphisms in the tumor necrosis factor alpha and interleukin 1-beta promoters with possible gene regulatory functions increase the risk of preterm birth. Acta Obstet Gynecol Scand 2008;87: 1285-1290.

22 Romero R, Velez Edwards DR, Kusanovic JP, Hassan SS, Mazaki-Tovi S, Vaisbuch E, Kim CJ, Chaiworapongsa T, Pearce BD, Friel LA, Bartlett J, Anant MK, Salisbury BA, Vovis GF, Lee MS, Gomez R, Behnke E, Oyarzun E, Tromp G, Williams SM, Menon R: Identification of fetal and maternal single nucleotide polymorphisms in candidate genes that predispose to spontaneous preterm labor with intact membranes. Am J Obstet Gynecol 2010;202:431.e1-431.e34.

23 Sata F, Toya S, Yamada H, Suzuki K, Saijo Y, Yamazaki A, Minakami H, Kishi R: Proinflammatory cytokine polymorphisms and the risk of preterm birth and low birthweight in a Japanese population. Mol Hum Reprod 2009; 15:121-130.

24 Engel SA, Erichsen HC, Savitz DA, Thorp J, Chanock SJ, Olshan AF: Risk of spontaneous preterm birth is associated with common proinflammatory cytokine polymorphisms. Epidemiology 2005;16:469-477. morphism and spontaneous preterm birth Am J Obstet Gynecol 2003;189:915-918.

26 Warren JE, Nelson LM, Stoddard GJ, Esplin MS, Varner MW, Silver RM: Polymorphisms in the promoter region of the interleukin-10 (IL10) gene in women with cervical insufficiency. Am J Obstet Gynecol 2009;201:372.e1-372.e5.

$27 \mathrm{Wu}$ W, Clark EA, Stoddard GJ, Watkins WS, Esplin MS, Manuck TA, Xing J, Varner MV, Jorde LB: Effect of interleukin-6 polymorphism on risk of preterm birth within population strata: a meta-analysis. BMC Genet 2013;14:30.

28 Thiel S, Moeller-Kristensen M, Jensen L, Jensenius JC: Assays for the functional activity of the mannan-binding lectin pathway of complement activation. Immunobiology 2002; 205:446-454.

29 Van Hoeyveld E, Houtmeyers F, Massonet C, Moens L, van Ranst M, Blanckaert N, Bossuyt $\mathrm{X}$ : Detection of single nucleotide polymorphisms in the mannose-binding lectin gene using minor groove binder-DNA probes. J Immunol Methods 2004;287:227-230.

30 Mølle I, Steffensen R, Thiel S, Peterslund NA: Chemotherapy-related infections in patients with multiple myeloma: associations with mannan-binding lectin genotypes. Eur J Haematol 2006;77:19-26.

31 Garred P, Larsen F, Seyfarth J, Fujita R, Madsen HO: Mannose-binding lectin and its genetic variants. Genes Immun 2006;7:85-94.

- 32 Goncalves LF, Chaiworapongsa T, Romero R: Intrauterine infection and prematurity. Ment Retard Dev Disabil Res Rev 2002;8:3-13.

33 Fishman D, Faulds G, Jeffery R, MohamedAli V, Youdkin JS, Humphries S, Woo P: The effect of novel polymorphisms in the interleukin-6 (IL-6) gene on IL-6 transcription and plasma IL-6 levels, and an association with systemic-onset juvenile chronic arthritis. J Clin Invest 1998;102:1369-1376.

- 34 Adams KM, Eschenbach DA: The genetic contribution towards preterm delivery. Semin Fetal Neonatal Med 2004;9:445-452.

- 35 Christiansen OB, Kilpatrick DC, Souter V, Varming K, Thiel S, Jensenius JC: Mannanbinding lectin deficiency is associated with unexplained recurrent miscarriage. Scand J Immunol 1999;49:193-196.

36 Christiansen OB, Nielsen HS, Lund M, Steffensen R, Varming K: Mannose-binding lectin-2 genotypes and recurrent late pregnancy losses. Hum Reprod 2009;24:291-299.

37 Kilpatrick DC, Starrs L, Moore S, Souter V, Liston WA: Mannan binding lectin concentration and risk of miscarriage. Hum Reprod 1999;14:2379-2380.

38 Kruse C, Rosgaard A, Steffensen R, Varming $\mathrm{K}$, Jensenius JC, Christiansen OB: Low serum level of mannan-binding lectin is a determinant for pregnancy outcome in women with recurrent spontaneous abortion. Am J Obstet Gynecol 2002;187:1313-1320. Caritis SN: Interleukin- 6 promoter -174 poly- 